\author{
Paolo Driussi \\ Università degli Studi di Udine \\ paolo.driussi@uniud.it
}

\title{
FUNKCIONÁLIS MEGKÖZELÍTÉS \\ A NYELVTANÍTÁSBAN
}

\section{Bevezetés}

A tanulmányban felvetett gondolatokat gyakorlati megfigyelések inspirálták, abból a kérdésből kiindulva, hogy a nyelvtanítás során diákjainkat mire és hogyan kell tanítanunk.

A világ, illetve az emberek közti kapcsolatok gyors tempóban változnak, így könnyü észrevenni, hogy a diákok viselkedése és attitűdjei is időről időre változnak, és olyan tudással, elöítéletekkel és szokásokkal rendelkeznek, amelyek messze nem azonosak azzal, amit húsz, harminc vagy negyven évvel ezelőtt tapasztaltunk. Mást várnak a tanáraiktól, másra figyelnek, és másra van szükségük, mint amire - mondjuk - a most ötvenéveseket tanították.

A nyelvtanítás hosszú ideig a hagyományos nyelvtani normákon vagy leírásokon alapult. A 20. században a világháborúk, az egyre bővülő nemzetközi kereskedelem, a közoktatás és a turizmus miatt is nagyon megváltozott a helyzet, hiszen szélesedett a nyelveket tanulók száma. Mindezek során a nyelvtanítás is megváltozott, mutatják ezt például az amerikai katonai nyelvtanítási módszerek (Bárdos 2005: 93-95).

Az elmélet egyre inkább háttérbe szorult, ennek ismeretét egyfajta magasabb kompetenciának tartották és tartják ma is. A nyelvtanítás nemcsak anyanyelvűeknek szólt, hanem egyre inkább kiterjesztették külföldiekre. Újabban pedig vegyes és egyre tarkább nemzetközi csoportoknak tanítjuk a nyelveket. A nyelvtanítás célja megváltozott, vele együtt a módszerek is, amelyek helyzetekhez, elméletekhez, piachoz igazodnak (Driussi 2015).

A nyelvészet egyre inkább foglalkozik a spontán beszéd vizsgálatával is. Az utóbbi negyven évben pedig egyre fontosabb szerepet kap a beszédprodukció folyamatának kutatása, amelyre különböző neurolingvisztikai modellek is épülnek. Éppen ezek a modellek helyezik új perspektívába a nyelvleírást és nyelvtanítást is. Éppen ezek a modellek helyezik új perspektívába a nyelvleírást és nyelvtanítást is. Közös kiindulópontjuk, hogy a pragmatika hierarchikusan megelőzi a lexikai kiválasztást, valamint a morfoszintaxist. Funk szerint Bock és Levelt modellje az, amelyet néhány éve újraértékelnek a nyelvtanításban (Funk 2012: 301).

Általában elmondható, hogy a beszédprodukció modelljei közel állnak a funkcionális megközelítésekhez, hiszen - szemben a hagyományos leírásokkal - a top-bottom, tehát 
felülről lefelé irányuló elemzés jellemzi őket. Egyben támogatják a kilencvenes években megvalósult lexikális megközelítéseket a nyelvtanításban (Funk 2012: 300).

A jelen tanulmány következőképpen épül fel: A 2. részben a Levelt-, illetve BockLevelt-féle beszédmodellt és nyelvtant ismertetem, hogy megmutassam, hol helyezkedik el a neurolingvisztika alapján a hagyományos, illetve a kognitív nyelvtani megközelítés. A 3. részben szembeállítom ezekkel Werlich szövegnyelvtanát, bevezetve a funkcionális megközelítést a nyelvelemzéshez és a nyelvtanításhoz. A 4. részben a nyelvtani elméleteket, valamint a nyelvtanításban való alkalmazáshatóságukat tárgyalom. Az 5. részben példákkal erősítem meg a cikkben kifejtett nézeteket, amelyeket a 6., befejező részben összegzek.

\section{A beszédprodukció}

2.1. A beszédprodukció vagy nyelvprodukció az a folyamat, amely (írott, szóbeli vagy jelszerü) formát ad a nyelvnek, és a közlés szándékától a kiejtésig vezeti a beszélőt. A beszédmodellek közül Wilhelm Levelté (1989) különösen érdekes, hiszen a lehetséges kritikák ellenére kiállja az idő próbáját. Ez a modell teljes vázlatát adja a nyelvi közlésnek, ezért hasznosnak tűnik különböző nyelvi megközelítések összehasonlításában is. Fontos észrevenni, hogy ha más-más is a célja és a látóköre a nyelvi elemzésnek, maga a közlés célja, a nyelvi kimenet, az üzenet mégis egyértelmű. De a nyelvi kód, a lexikon, az enciklopédikus tudás, a helyzetismeret, a kognitív hátterek nyelvenként és kultúránként különböznek, és különböző közlési akaratokat eredményezhetnek.

Továbbá szembetűnő a beszédprodukció modelljeiben, hogy erősen kötődnek a hallgató tevékenységéhez, tehát a hallgatás által motivált interpretációhoz, beszédelemzéshez.

Az 1. ábra Levelt szerint a beszélő tervezetét mutatja. Az eredeti címkéknek a következő magyar megfelelőit ajánlom (figyelembe véve Gósy 2005 és Magyari 2014 megoldásait is), de az ábrákon az egyértelműség érdekében megtartom az angol kifejezéseket.

\section{CONCEPTUALIZER: FOGALOMALKOTÁS}

Message generation: az üzenet generálása

Monitoring: ellenőrzés

Preverbal message: preverbális üzenet

FORMULATOR: MEGFORMÁZÁS/MEGSZÖVEGEZÉS

Grammatical encoding: grammatikai kódolás

Surface structure: felszíni szerkezet

Phonological encoding: fonológiai kódolás

Phonetic plan: fonetikai terv

ARTICULATOR: ARTIKULÁTOR

Overt speech: hallható beszéd 


\section{AUDITION: HALLÁS}

Phonetic string: fonetikai lánc

SPEECH COMPREHENSION SYSTEM: BESZÉDMEGÉRTŐ RENDSZER

LEXIKON lemmas/forms: LEXIKON lemmák/alakok

Parsed speech: elemzett beszéd

Discourse model, situation knowledge, encyclopedia etc.: diskurzusmodell, helyzetismeret, enciklopédikus tudás stb.

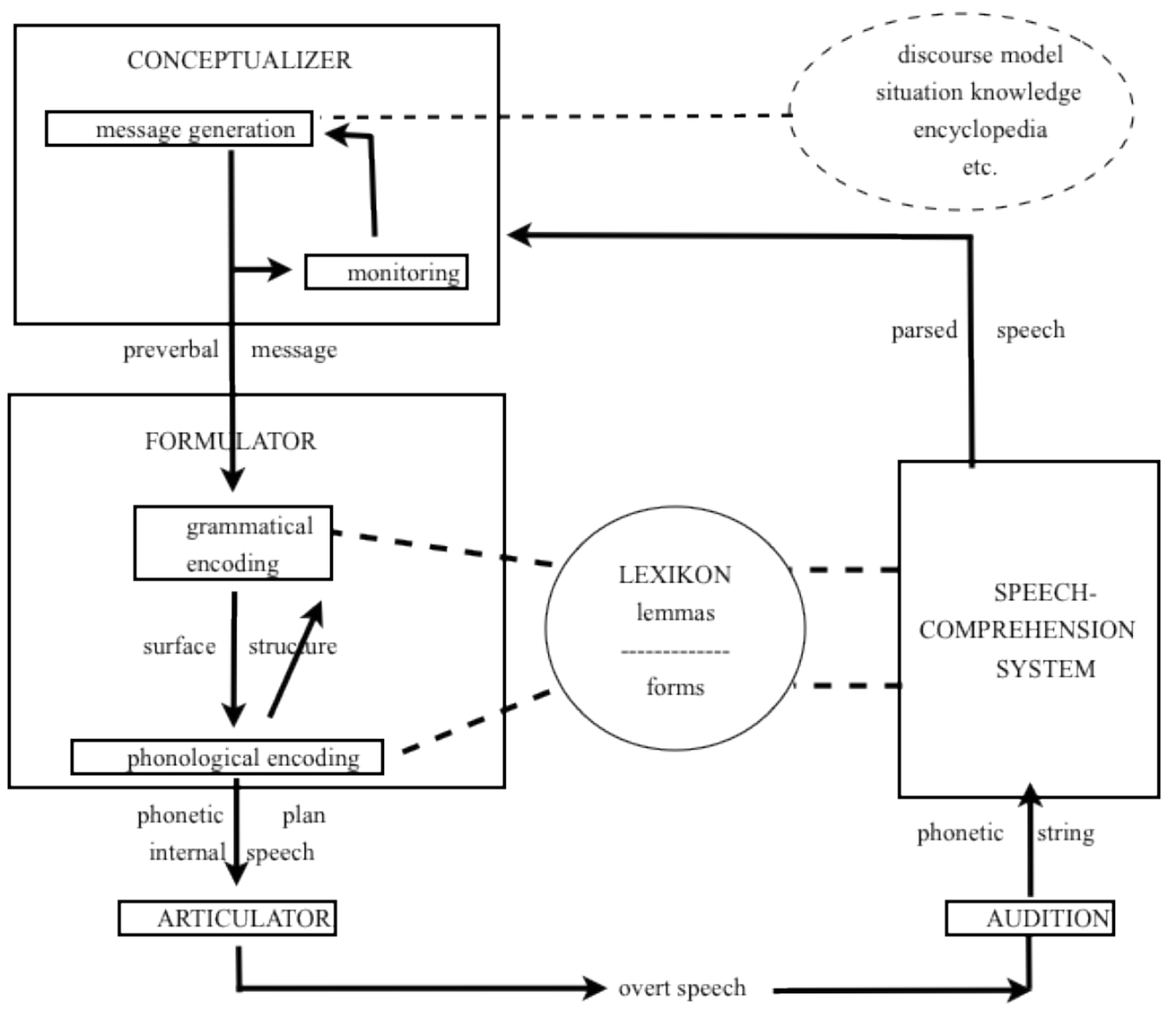

1. ábra: A beszélő mint információkövető (Levelt 1989: 9 alapján).

Az ábra alapján észrevehető, hogy a modellt elsősorban folyamatok jellemzik, és a nyelvprodukció középpontjában az ismeretek állnak, grammatikaiak és lexikálisak egyaránt.

A modell szerint a beszélő elsősorban megfogalmazza a közölnivalót ahhoz, hogy üzenetet hozzon létre. Ha a mondanivaló el van képzelve, kódolni kell, megfelelő nyelven, megfelelő szabályok szerint. 
2.2. Megjegyzendő, hogy maga a nyelvtan, a kódolás csak egy része a modellnek. A modellben szerepet játszik a fogalomalkotás (conceptualizer), amely irányítja a preverbális üzenetet, illetve a közlési szándék. A fogalomalkotó a nyelven kívül áll, és megelőzi a kódolást. Továbbá a (hallgató által végzett) beszédértelmezés visszajelzést ad a fogalomalkotónak. A hallható beszéd a beszélő és hallgató összekapcsoló eleme, de a beszéd kifejtése (írásban, jelben vagy beszédben) kívül esik a kódoláson. A hallás mozgósítja nyelvi ismereteit a hallgatónak, aki a nyelvtani ismereteire támaszkodva elemezheti a közlést és rekonstruálhatja a beszélő fogalmazását. Ehhez a lexikon elemei szükségesek, valamint a diskurzusmodell, a helyzetismeret és az enciklopédikus tudás. Ez az utolsó három tényező a kognitivizmus tárgya. Míg magát a nyelvtant szabályok és megszorítások jellemzik, a kognitív magyarázatok éppen a beszélő világismereteire és világképére hivatkoznak.

2.3. Bock és Levelt későbbi elképzelésében (Bock-Levelt 1994) a grammatikát mint nyelvi produkciót két folyamat jellemzi: a funkcionális és az elhelyezési (pozicionális). Ezt a 2. ábra mutatja. Ebben az esetben is megadom az általam választott magyar megfelelőket (Gósy 2005 és Magyari 2014 alapján is):

MESSAGE: ÜZENET

FUNCTIONAL PROCESSING: FUNKCIONÁLIS FELDOLGOZÁS

Lexical selection: lexikális szelekció

Function assignment: funkcionális kódolás

POSITIONAL PROCESSING: POZICIONÁLIS FELDOLGOZÁS

Constituent assembly: szavak sorrendje

Inflection: ragozás

PHONOLOGICAL ENCODING: FONOLÓGIAI KÓDOLÁS

To output systems: kimeneti rendszerekhez

Egyértelmű, hogy a hagyományos nyelvtanok a kódoló résszel foglalkoznak (l. az 1. ábrát), azon belül pedig a morfoszintaxissal, az elhelyezési rendszerrel. Sőt: külön kezelik a morfológiát és a szintaxist. A Magyar grammatika (Keszler szerk. 2000) egyértelműen kizárja a fonológiát a grammatika köréből, míg $A$ mai magyar nyelv rendszerében (Deme 1962) a fonológia, pontosabban a hanglejtés nagy szerepet játszik. A jelentéstan pedig nem tartozik a hagyományos grammatikák tárgykörébe. 


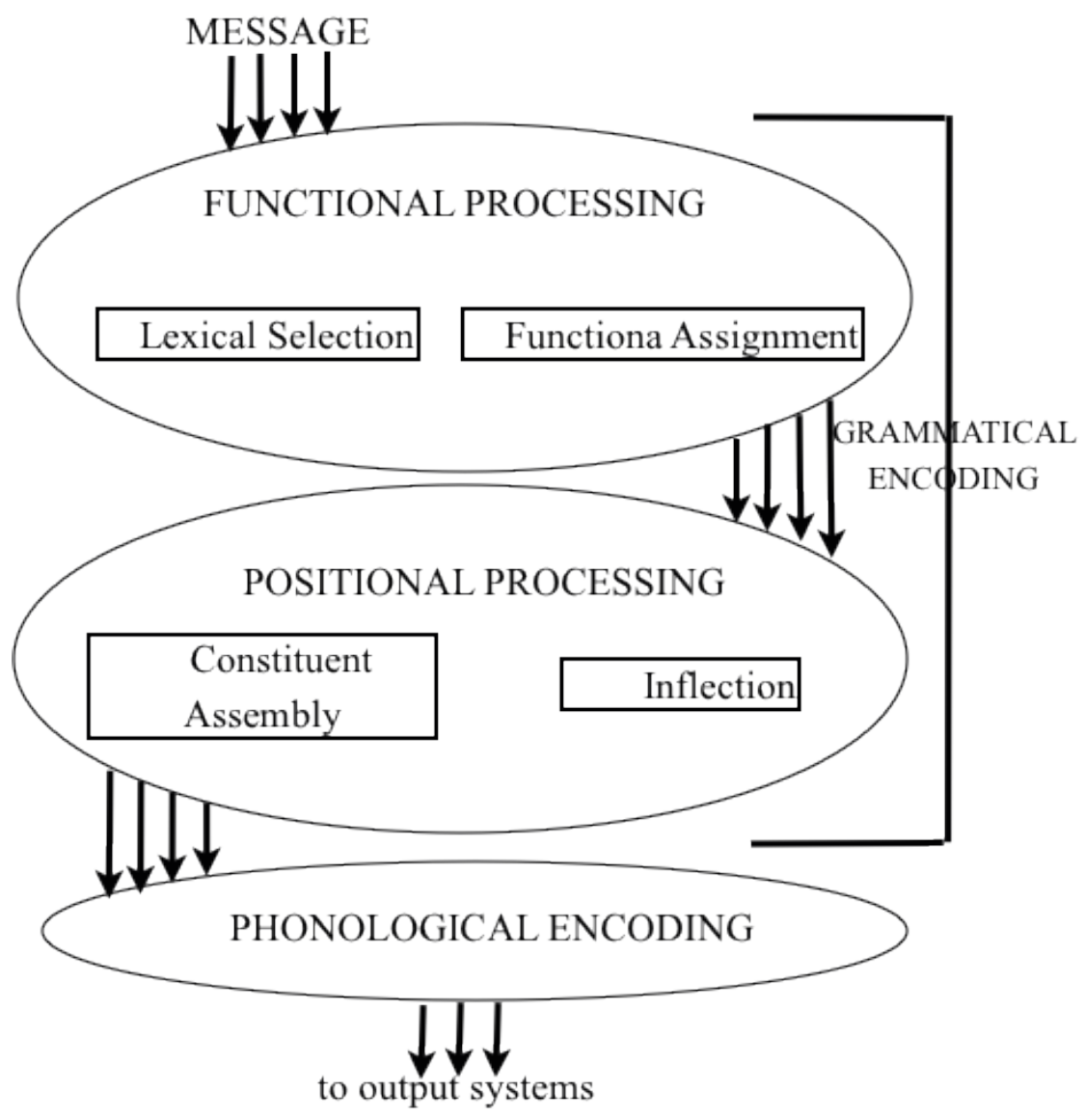

2. ábra: A beszédprodukció áttekintése (Bock-Levelt 1994: 946 alapján)

2.4. Bock és Levelt modelljében a szókincs elkülönül a nyelvtantól. Szemben a hagyományos nyelvtannal, a lexémák nem a pozicionális feldolgozáshoz tartoznak, hanem a funkcionális feldolgozáshoz, és testes részévé válnak a beszédprodukció elemzésének. Levelt modellje szerint tulajdonképpen a hallgató beszédmegértő rendszerében is közremüködnek, de itt most csak a produkció oldalával foglalkozunk.

Pontosan hogyan játszik szerepét a szókincs? A lexikonban szemantikus és aszemantikus elemek szerepelnek, valamint olyanok is, amelyek a beszédhelyzettől függően tartozhatnak valamelyik kategóriához. A szemantikus elemek bizonyos szerkesztési igényekkel járnak együtt, azaz: a konkrét jelentésük mellett, a beszélő a hozzájuk kapcsolódó vonzatokat is ismeri, valamint esetleges kollokációkat vagy elhelyezési megszorításokat. A beszédprodukció során ezeket a megfelelő pillanatban kell használni, megfelelő ragokkal és jelekkel, amelyeket szintén a lexikonból merítünk. A mindebből eredő szerkezet segíti majd a(z ugyanolyan kódot ismerő) hallgatót a megértésben. 
Továbbá a beszédprodukciós modellben, akár a tiszta funkcionális nyelvtani megközelítéseknél, maga a beszéd áll a középpontban, nem a mondat. Fontos leszögezni: ha szövegekkel foglalkozunk, akkor nem dolgozhatunk olyan merev szabályokkal, mint amilyenek a nyelvtanokra jellemzők. Szabályok azonban a beszéd szerkesztésében is érvényesülnek. Mivel a hagyományos nyelvtanok csak a mondaton belüli értelmezéssel foglalkoznak, csak a legnyilvánvalóbb kapcsolatokat mutathatják ki. A neurolingvisztikai elemzés során ezzel szemben a hallgató minden ismeret alapján újraszerkeszti és értelmezi a beszédet, így könnyen észreveheti a hosszabb szövegek nyelvi hálózatát, hiszen nemcsak a nyelvi formákat veszi figyelembe, hanem magát a folyamatot is, amely ezeket létrehozta. Gondoljuk például a hiányos mondatokra, amelyeket csak a helyzet, az előzmény által lehet megérteni. Pontosan ezért merülhet fel a kérdés, hogy mi a viszony a hagyományos nyelvtan és az aktuális nyelvi közlés között, hiszen a legtöbb szöveg sokkal inkább számos mondatból áll össze, nem csak kettőből vagy háromból. Ezeket a szemléletbeli különbségeket hidalja át Egon Werlich (1976) angol szöveggrammatikájában.

\section{A grammatika és a szöveg viszonya: Werlich megközelítése}

3.1. Werlich munkájában éppen olyan megközelítést használ, mint amilyet néhány évvel később a neurolingvisztika különböző beszédmodelljei részletesen elemeztek. A beszélő közlési szándékából indul ki, és annak alapján leírja a közlés kifejtéséhez vezető folyamatokat, amelyek végeredményben a hagyományosan vett nyelvtant alakítják. A felhasznált nyelvi eszközök jelentéssel és funkcióval is rendelkeznek, és e kettő alapján valósítják meg a beszélő akaratát. Werlich nyelvtanában a beszélő áll a középpontban, és a nyelvtan feladata, hogy segítsen a beszélö közlésének legsikeresebb értelmezésében.

3.2. Werlich neve elsősorban a szövegtípusok felismeréséről, felosztásáról ismert (Werlich 1975). Az angol szöveggrammatikában Werlich (1976) megmutatja, milyen közlési tényezők játszanak szerepet a mondatszerkezetben a klasszikussá vált szövegtípusok elkülönítésére. Mindezeket a 22. oldalon egy egyszerü ábrán mutatja meg, amelyből felismerhető a beszélő akarata, a megkívánt közlési szándék és az aktuális üzenet felszíni szerkezetének a szoros kapcsolata. Werlich megemlíti, hogy egy adott kontextusban (context), amely a hallgató (addressee) tárgyi világában (objects) létezik, a beszélő (speaker) bizonyos észlelések szempontjából szerkesztheti a szövegét. A tér észlelése (perception in space) leíró szövegeket hoz létre (description). Az idő észlelése (perception in time) narratív, elbeszélö szövegeket (narration) jellemez. A megértés (understanding) értelmi szövegekhez vezet, az ítélet (judging) pedig érveléshez (argumentation). Végül a tervezési szándék (planning) parancsokkal realizálódik.

3.3. Érdekes módon kezeli Werlich a nyelvtan különböző elemeit. Ragokat, jeleket, képzőket, prepozíciókat, segédigéket csak mellékesen említ, azok tulajdonképpen merev 
elemei a nyelvnek, szabályai valamilyen módon kötöttek. Ez a fajta elemzés az idegen nyelvek tanításában fontosnak bizonyult, de kevésbé fontos, ha anyanyelvüeket tanítunk (Werlich 1976: 13). Ez utóbbi esetben inkább a szavak kiválasztása játszik fontos szerepet, (belső) szerkezetükkel együtt. Központi helyet kap a szavak funkciója, különösen a szövegek típusához képest.

3.4. Werlich a szövegek szerkesztése mentén építi fel nyelvtanát. Igény szerint, a közlés bizonyos pragmatikai döntései (points of view) alapján ki kell választani a lexikonból a legalkalmasabb kifejezéseket, határozószókat, kötőszókat. A szövegnek van egy kezdete, egy központi része, valamint egy lezárása. Mindezeket másképpen kell szerkeszteni, és a különböző szövegtípusoknak megfelelően kell egymással összekapcsolni. A döntésben szerepet játszik a modalitás, a határozottság, az abszolút időbeli viszony. A szöveg egységei a mondatok, melyeket persze ténylegesen létre is kell hozni, ki kell ejteni. Mindezek alapján megfigyeli, hogy az anyanyelvűek tudják, hogyan kell használni a különböző mondatrészeket, de a jó közlés nem azokból áll, hanem egy kellően hatékony szerkezetből. Ezt kellene az anyanyelvű diákoknak megtanítani.

3.5. Remélem, hogy a felsoroltak alapján egyértelmű, hogy Werlich a pragmatikai tényezőktől indítja a közlés leírását. Nyelvtana elsősorban a sokféle modalitás részletes leírását adja. Így a formális angol nyelvnek is megmutatja a funkcionális tényezőit. Amikor leírja a legkisebb mondatrészeket, tulajdonképpen a funkcióikra utal (Werlich 1976: 198-203). A nyelv szabályait a beszélő közlési akarata alapján kell használni. Könyvének legelején a szerző világosan kiemeli munkája kognitív és funkcionális jellegét, hangsúlyozva, hogy az interakciós és közlési készség funkcionális oldalát akarja alaposan tanulmányozni.

\section{Megfigyelések a funkcionális megközelítésekről}

4.1. Azt mondhatjuk, hogy a nyelvtan funkcionális megközelítése egy lépéssel közelebb hozza Werlich modelljét Levelt beszédmodelljéhez, mert a funkcionalizmus a pragmatikát fontosabbnak tartja a szemantikánál és a morfoszintaxisnál, bár a nyelvnek minden szintjét számba veszi a nyelvtan magyarázatára, mint például Halliday (1985) elméletében. Tolcsvai Nagy Gábor (2005) párosítja ezt Talmy Givón angol nyelvtanával (1993), bár annak szerkezete erősen hajlik a hagyományos formalizmus felé. Givón még közel áll a hagyományos nyelvtanokhoz, de elismeri a discourse coherence-t, a szöveg koherenciáját, amely testtel látja el a szavak által adott jelentést, a mondatok által nyújtott információt, valamint részletesen foglalkozik a modalitással.

4.2. Werlichnek fontos meglátása, hogy a mondatgrammatikák fontosak az idegennyelv-tanításban, de emelett a tiszta funkcionális megközelítések is hasznosak lehetnek. Ujjabban a Functional Discourse Grammar, a szöveg funkcionális nyelvtana (a továbbiakban FDG, 
Hengeveld-Mackenzie 2008) közvetlenül Levelt beszédmodelljéből indul ki. Eredeti célja a világ nyelveinek tipológiai kutatása. Ezért minden lehetséges nyelvi szerkezetet, tulajdonságot vizsgál, tehát minden nyelvre alkalmazható. De az FDG egyben formális is (l. erről Butler-Gonzálvez-García 2005), és bár elsősorban a beszéd létrehozását vizsgálja, a megfogalmazástól a kiejtésig kellő részletességgel írja le, hogy a hallgató elemzését is elősegítse. Szemben Halliday vagy Werlich nyelvtanával, az FDG a teljes nyelvtannal foglalkozik, mind a szöveges részével, mind a kisebb egységekkel, a mondatrészekkel, egészen a fonológiáig. Ezért felhasználható lehet a nyelvek L2-ként való tanításában is. Részben említi ezt Giomi (2014), de magam is évek óta tapasztalom, amikor olasz anyanyelvűeknek tanítom a magyart mint idegen nyelvet.

4.3. Egyesek a kognitív nyelvészetet is funkcionálisnak tartják, de az leginkább a helyzetismeretre és az enciklopédikus tudásra irányítja a figyelmünket, tehát bővíti, szélesíti a nyelvhasználati kört, a lexikonhoz köti elemzését, és onnan fordul a funkció felé. Az 1. ábra alapján azt mondhatjuk, hogy a kognitív megközelítés elsősorban a szaggatott vonallal körbevett elemekre összpontosít. Ha következetesen megvizsgáljuk az ábrát, azt látjuk, hogy ezek az elemek állnak legmesszebb a nyelvtani összetevőktől. Ez az elemzési mód véleményem szerint anyanyelvi szintủ ismeretet kíván meg, mivel nyelvspecifikus képzetekhez kötődik.

4.4. A felsorolt elemzések, elméletek szerint tehát a szöveg, a diskurzus mint komplex összetevő áll a közlés középpontjában. Werlich modelljének tanulsága (1976), Halliday elképzelése (1985), Van Dijk művei (1980, szerk. 1997) mind arra irányítják a figyelmünket, hogy a nyelvet nemcsak nyelvórákon tanuljuk, hanem minden olyan esetben, amikor használjuk, illetve amikor sikeres interakció jön létre beszélő és hallgató között. Funk (2012: 308) jól összegzi a különböző funkcionális nézetek nyelvoktatásbeli hatását, amikor azt állítja, hogy a leginkább explicit formális irányításokat a legkevésbé felkészült tanárok adják, míg a legtapasztaltabbak ezeket a beszédgyakorlatok során hozzák egyensúlyba.

A teljes szöveg koherenciáját kell mindenképpen felhasználni, és így megmutatni a hallgatóknak, gyakoroltatni velük, akár passzívan is. Ebből a szempontból a funkcionális megközelítések azt hangsúlyozzák, hogy a nyelv egy általános közlési eszköz, és a kommunikáció sikerében általános neurolingvisztikai tényezők érvényesülnek. Érdemes-megjegyezni ezt a megfigyelést, hiszen részben motiválhatja a diákokat, részben közös alapot nyújt a nyelvpedagógiához.

A funkcionális megközelítés szerint semmiképpen sem a mondatgrammatika áll a középpontban, hanem az valójában együttműködik a funkcionális jelenségekkel. Már láttuk, hogy maga a hagyományos nyelvtan tulajdonképpen az elhelyezési szabályok a leírása. Ezek „kötött” szabályok. A beszéd kényszerekből áll, de választható kényszerekből, amelyek szorosan kötődnek a megkívánt beszéd funkciójához. 
Ahogyan Werlich alapján is állíthatjuk, és amit Lambrecht 1994-es könyvében tisztáz, a mondatszerkezet a pragmatikai kódolásától függ. Levelt és Werlich nemcsak a nyelvprodukcióra, hanem a nyelvtanításra is vonatkoztatta ezt a nézetet. Mindezek alapján követendőnek tartom a funkcionális megközelítést, amely a nyelvhasználatban megállapítja a pragmatika elsőbbségét a szemantika és a morfoszintaxis fölött.

\section{Példák a funkcionális megközelítésre}

5.1. Werlich (1976) már a bevezető fejezetben azt hangsúlyozza, hogy a sikeres közléshez a szöveg felépítésének alapos ismerete szükséges. Az anyanyelvűekkel ennek használatát érdemes kicsiszolni, hiszen már elsajátították a mondatgrammatikát, az idegen nyelvet tanulókat viszont ez utóbbira is meg kell tanítani.

Saját tapasztalataim alapján is érdemes feltenni a kérdést, hogy mi történne, ha az idegen nyelv tanítása során a pragmatikai tényezőket a morfoszintaxis szabályaival együtt tanítanánk. Talán lassabban haladnánk az órák legelején, azután viszont aktualizálódna a diákok ismerete, és az elhelyezési szabályok, a ragozási szabályok könnyü megformálási kérdésként mutatkoznának meg, amelyek csak segítenek tisztázni a közlésünket egy adott nyelvben. Ezt a nézetet az előbb említett Funk szavai is alátámasztják.

Úgy látom, ez különösen igaz abban az esetben, ha olyan nyelveket tanítunk, amelyek nyelvtana lényegesen eltér a diákok anyanyelvétôl vagy első tanult nyelvétől. Sokszor az azonos elnevezésű mondatrészek használata az anyanyelvben és a célnyelvben teljes mértékben különbözik. Ebben segíthet a funkcionális megközelítés, ahogyan ez az előző alfejezetekből is következik.

5.2. A funkcionális elemzést különösen sürgeti, és épp a magyar nyelvet is érinti, a szenvedő igék szerkezete. Ma már nemcsak a funkcionális elméletek mutatják, hogy ennek a lényege nem annyira a tárgy alannyá válása, hanem az információ perspektívája, Sansò (2013) szavaival: a topikalizáció. A World Atlas of Linguistic Structures passzívról szóló oldalán Siewierska (2013) öt pontot sorol fel, amelyek jellemzik a szerkezetet. A negyedik éppen azt hangsúlyozza, hogy a szerkezet pragmatikailag korlátozott, szemben az aktívval. A témát röviden összefoglalja Driussi (2018).

A funkcionalizmushoz éppen az az információs perspektíva közelíti a szenvedő alakokat, amelyet Levelt (1989) funkcionális szerkezetnek, Lambrecht (1994) pedig információs szerkezetnek nevez. Ennek alapján jön létre a felszíni szerkezet, amely a (grammatikai) kódolás által kifejtendő mondattá válik. Természetesen a kódolás nyelvenként különbözik. A magyarban a szórend által lehet topikálizálni egy mondatrészt, az olaszban pedig a tárgyragos szintagmának alannyá kell válnia.

Érdekes módon 2018-as kutatásom (Driussi 2018) azt mutatta meg, hogy nem magyar anyanyelvü fordítók fordításaikban megtartják az eredeti magyar aktív, azaz nem szenvedő szerkezeteket, elhanyagolva a topikalizáció fontosságát. Azok a magyar 
anyanyelvűek azonban, akik idegen nyelvre fordítanak, szívesen használják a szenvedő szerkezet pragmatikai jellegét, ha jobban megfelel az eredeti közlési szándéknak. Ez az észrevétel azt sürgeti, hogy amikor jól ismerünk egy adott funkciót, akkor bármely nyelven megfelelőképpen kezeljük. A fókusz rendszeres nyelvtani kódolása a magyarban, a topikalizálás fontossága ösztönzi a fordítókat, hogy megtalálják az idegen nyelvi megfelelőt. Mivel azonban az olasz nyelvben kevésbé fontos és nyelvtanilag nincs rendszerszerủen használva a topikalizálás, az olasz fordítók nem értik a topikalizáció fontosságát, hanem úgy kezelik a magyar mondatot, mintha szabad lenne a szórendje. Amennyiben lehetséges, az olasszal azonos szórendet használnak. Deme szavait figyelmen kívül hagyva úgy vélik, elég, ha szóról szóra fordítanak: „A szórend szabadsága nyelvtani értelemben veendö, azaz mindössze annyit jelent, hogy nyelvünk az egyes mondatrészek viszonyát ragokkal és egyéb elemekkel jelöli meg, s így a szórend nem morfematikusan (azaz nem mondatrészek minőségének és viszonyának jelölésére) felhasznált eszköze" (Deme 1961: 137).

Számomra ez akkor vált különösen fontossá, amikor magyar nyelvet kezdtem tanítani olaszoknak. Mostanában azzal kezdem a nyelvtanítást, hogy beszéltetem a diákokat, és figyelmeztetem őket a pontos közlési szándékuk megértésére. Megfelelö kérdésekkel a diákok észrevehetik, hogy milyen változatos a beszédük, milyen pragmatikai funkciókat használnak öntudatlanul. Ennek ismeretében a nyelvtanár megtaníthatja őket arra, hogy hogyan lehet más nyelven kifejteni azokat a bizonyos funkciókat. Vagy azt, hogy néha el kell kerülni az anyanyelvük bizonyos funkcióit, mert az adott célnyelv nem tartja olyan fontosnak, hogy beillessze a grammatikai rendszerébe.

5.3. Egy ilyen elkerülendő funkció az orosz aspektus, ha olaszra fordítunk. Olaszul az aspektuálitást tulajdonképpen aktionsart mozzanatokkal fejezzük ki, elsősorban lexikális eszközökkel. Mivel pedig legtöbbször elkerüljük, megjelölése inkább érzelmi állapotot fejez ki. Tehát nincs értelme magának a perfektív-imperfektív szembenállásának.

A következő példákban, ahol az orosz szembeállítja az aspektust, olaszul épp ugyanolyan igealakot használunk, az időhatározó elősegíti az értelmezést, illetve az aspektuális jellegű befejez segédige.

(1) а. Она две недели читала эту книгу.

b. Lei ha letto questo libro per due settimane.

Itt az igealak: ha letto, és a mondat fordítása 'Ő két hétig olvasta ezt a könyvet'.

(2) a. Она прочитала эту книгу за две недели.

b. Lei ha letto questo libro in due settimane. 
Az igealak azonos az előzővel. Fordítása: 'Két hét alatt olvasta el ezt a könyvet'; vagy Lei ha finito di leggere il libro in due settimane. Itt pedig ha finito di leggere az igei szintagma, szó szerinti fordításban: 'két hét alatt fejezte be az olvasást'.

Megjegyezhetjük, hogy néha az aspektuális oppozíciót határozottság révén mutathatjuk meg, ahogyan a következő példákban:

(3) a. Я джинсы покупал.

b. Ho comperato jeans. Fordítása: 'Farmernadrágot vettem.'

(4) а. Я джинсы купил.

b. Ho comperato i jeans. Fordítása: 'Megvettem a farmernadrágot.'

Mindkét mondatban az olasz ige ho comperato alakban szerepel. A határozottságot az $i$ szócska jelzi, amely hímnemủ, többes számú határozott névelő.

Különösen problematikus az olaszból oroszra fordítás, hiszen annyira elkerüli az aspektust a kiinduló nyelv, hogy néha a fordítónak kell eldönteni, melyiket kell használni a célnyelven.

5.4. Magyar és olasz összevetésben két esetet emelnék ki. Ami a grammatikai kódolást illeti, figyelmet igényel az olasz ma kötőszó használata, hiszen magyarra olykor a de, máskor a hanem szócskával fordítható. Néhányszor a pedig is használatos, de az a tuttavia vagy $e$ kötőszónak is lehet a megfelelője. Ilyenkor a hagyományos nyelvtan is törekszik annak magyarázatára, hogy milyen funkcióban szerepel a mondatban a szó: megszorítást, ellentétet, ok-okozati viszonyt fejez-e ki.

Érdekes módon, ha a magyar nyelvből indulunk ki, akkor elég a formális megfelelés: amikor de vagy hanem kötőszó szerepel a mondatban, mindig a ma szócskát használjuk olaszul. Kivétel a De jó! típusú használatban, amely kollokáció, és funkcióra utal. Olasz szövegek fordításában viszont szükségképpen csak a funkcióra kell hivatkoznunk. Akkor adhatunk megfelelő magyar fordítást, ha pontosan felismerjük a közlési szándékot.

(5) Vado via, ma la valigia rimane qui. 'Elmegyek, de itt marad a bőröndöm.'

(6) Non vado via, ma ti aiuto. 'Nem megyek el, hanem segítek neked.'

(7) Egli se ne andò, ma io rimasi a casa. 'Ö elment, én pedig itthon maradtam.'

A magyarban fontos szerepet játszik a közlésben az információs szerkezet is. Tudniillik a magyarban a topik és a fókusz (azaz a kiemelt mondatrész) elsődleges ismérv a mondat szerkezetében. Olaszul ritkábban használjuk a fókuszálást, amely erős érzelmi hatást gyakorol a hallgatóra. Az olasz fókuszálás kétféleképpen történhet. A balra kihelyezés és kiemelés irányító erővel hat a hallgatóra, és különösen hangsúlyos. Míg a beszédben gyakori, írásban szokatlannak tủnik. Érdekesebb a mondat utolsó pozíciójára eső fókusz, 
amely enyhén felhívja a figyelmet a fókuszos mondatrészre. E megoldás jobban müködik sok mondatrészt tartalmazó mondatokban, mégsem hivatkoznak rá a nyelvtanok.

Mindebből az következik, hogy amikor az alábbi példákhoz hasonló mondatokat kell fordítanunk, ajánlatos, hogy a szerkezet ugyanolyan érzelmet tükrözzön olasz nyelven. A fókuszos mondatrészt leginkább különösen erős hangsúllyal emeljük ki:

(8) Gianfranco ismeri Máriát. 'Gianfranco conosce Maria.'

(9) Gianfranco Máriát ismeri. „Gianfranco conosce "Maria.”

Ha balra helyeznénk a Mariá-t (10), a közlés egészen más jellegű lenne, mint a magyarban, hiszen inkább a (11)-nek felelne meg:

(10) È Maria, che Gianfranco conosce.

(11) Akit Gianfranco ismer, az Mária.

Ezeket a fordítási problémákat csak egy nyelv belső működésének pontos ismeretével lehet megoldani, azaz úgy, ha tudjuk, hogy mi az információ szerkezete, a közlési szándék, valamint azt is, hogy mindez hogyan realizálódik az adott nyelveken.

\section{6. Összegzés}

A különböző megközelítések közös kiindulópontja tehát a pragmatikai kompetencia. Amennyiben a beszélő felismeri a közlési szándék szerkezetét, annak megadhatja megfelelő alakját, grammatikai kódolását. Ez mindenképpen igaz az anyanyelvi nevelésben - ahogyan Werlich rámutatott. Ez az ismeret legalább annyira fontos, mint a részletesebb elhelyezési, grammatikai szabályok, amelyeket így is a gyakori használatból tanulhatunk meg. Fontos, hogy a beszélők ismerjék a pontos ragozási mintákat, de még hasznosabb, ha tudják, mikor és hogyan kell használni ezeket, hogy pontos és adekvát szövegek jöjjenek létre. Épp ez lehet a tárgya az anyanyelv tanításának is: a különböző típusú szövegszerkezetek nyelvtani magyarázata, à la Werlich. Ez az ismeret részben gyümölcsöző ösztönzés lehet idegen nyelvek megtanulására is. Ahogyan az anyanyelvűek számára, a nyelvet tanulók számára is érvényes lehet egy ilyen pragmatikai megközelítés. Mint említettem, tulajdonképpen a legújabb funkcionális nyelvtanok olyan mértékben formálisak, hogy alkalmasak az elhelyezési folyamatok tanítására is: a magyar esetében Hegedűs funkcionális mondattana ilyen (Hegedűs 2004).

Tanulmányommal arra igyekeztem felhívni a figyelmet, hogy bár nem egyszerű, mégis érdemes figyelembe venni a funkcionális szemléletet az anyanyelvi nevelés és az idegen nyelvek tanítása során egyaránt. 


\section{Irodalom}

Bárdos Jenő 2005. Élö nyelvtanítás-történet. Budapest: Nemzeti Tankönyvkiadó.

Bock, Kathryn - Levelt, Wilhelm 1994. Language production: Grammatical Encoding. In: Gernsbacher, Morton Ann (ed.): Handbook of psycholinguistics. San Diego: Academic Press. 945-984.

Butler, Christopher S. - Gonzálvez-García, Francísco 2005. Situating FDG in functional-cognitive space: An initial study. In: Mackenzie, J. Lachlan - De los Ángeles Gómez-González Maria (eds.): Studies in functional discourse grammar. Bern: Peter Lang. 109-158.

Deme László 1961. Köznapi fogalmazásunk mindennapi botlásaiból. (Negyedik közlemény.) Szórendi és sorrendi kérdések. Magyar Nyelvör 85/2: 137-147.

Deme László 1962. Hangsúly, szórend, hanglejtés, szünet. In: Tompa József (szerk.): A mai magyar nyelv rendszere. Leíró nyelvtan. II. kötet. Mondattan. Budapest: Akadémiai Kiadó. 458-522.

Driussi, Paolo 2015. A nyelvek változnak, és velük a nyelvet beszélők is. In: Gecső Tamás - Sárdi Csilla (szerk.): Nyelv, kultúra, társadalom. Székesfehérvár, Budapest: Kodolányi János Főiskola - Tinta Könyvkiadó. 59-64.

Driussi, Paolo 2018. Riflessioni sulle corrispondenze dell'uso di forme passive in una lingua che non le conosce. Studi Italiani di Linguistica Teorica e Applicata XLVII/3: 501-520.

Funk, Hermann 2012. Four models of language learning and acquisition and their methodological implications for textbook design. Electronic Journal of Foreign Language Teaching 9/1: 298-311.

Giomi, Riccardo 2014. Grammar, context and the hearer: a proposal for an addressee-oriented model of Functional Discourse Grammar. Pragmatics 24/2: 275-296. https://doi.org/10.1075/prag.24.2.05gio

Givón, Talmy (ed.) 1993. English grammar. A function-based introduction. Volume I. Amsterdam, Philadelphia: John Benjamins. https://doi.org/10.1075/z.engram2

Gósy Mária 2005. Pszicholingvisztika. Budapest: Osiris Kiadó.

Halliday, Michael A. K. 1985. An introduction to functional grammar. London, Victoria, Baltimore: Edward Arnold.

Hegedüs Rita 2004. Magyar nyelvtan. Formák, funkciók, összefüggések. Budapest: Tinta Könyvkiadó.

Hengeveld, Kees - Mackenzie, Lachlan 2008. Functional Discourse Grammar. A typologically-based theory of language structure. Oxford: Oxford University Press. https://doi.org/10.1093/oxfordhb/9780199544004.013.0015

Keszler Borbála (szerk.) 2000. Magyar grammatika. Budapest: Nemzeti Tankönyvkiadó.

Lambrecht, Knud 1994. Information structure and sentence form. Topic, focus, and the mental representations of discourse referents. Cambridge: Cambridge University. https://doi.org/10.1017/CBO9780511620607 
Levelt, Wilhelm J. M. 1989. Speaking: from intention to articulation. Cambridge, MA: MIT Press.

Levelt, Wilhelm J. M. 1995. The ability to speak: from intentions to spoken words. European Review 3/1: 13-23. https://doi.org/10.1017/S1062798700001290

Magyari Lilla 2014. A beszédprodukció. In: Pléh Csaba - Lukács Ágnes (szerk.): Pszicholingvisztika. Magyar pszichoilingvisztikai kézikönyv. 1. kötet. Budapest: Akadémiai Kiadó. 371-410.

Sansò, Andrea 2003. Degrees of event elaboration. Passive constructions in Italian and Spanish. Milano: Franco Angeli.

Siewierska, Anna 2013. Passive constructions. In: Dryer, Matthew S. - Haspelmath, Martin (eds.): The world atlas of language structures online. Leipzig: Max Planck Institute for Evolutionary Anthropology.

Tolcsvai Nagy Gábor 2005. Funkcionális nyelvtan: elmélet és gyakorlat. Magyar Nyelvör 129/3: 348-363.

Van Dijk, Theun A. 1980. Text and context. Explorations in the semantics and pragmatics of discourse. (First ed. 1977). London, New York: Longman.

Van Dijk, Theun A. (ed.) 1997. Discourse as structure and process. Discourse studies: A multidisciplinary introduction 1. London, New Delhi, Thousands Oaks: SAGE.

Werlich, Egon 1975. Typologie der Texte. Heidelberg: Quelle \& Meyer.

Werlich, Egon 1976. A text grammar of English. Heidelberg: Quelle \& Meyer.

\section{Internetes hivatkozások}

W1 = Humanities Commons https://digitalpedagogy.mla.hcommons.org/ (2019. 05. 10.) 